\title{
Impact of wetting-drying cycles on the mechanical properties of lime-stabilized soils
}

\author{
Maafi Nabil $^{\mathrm{a} *}$, Akchiche Mustapha $^{\mathrm{a}}$, Sara Rios ${ }^{\mathrm{b}}$ \\ ${ }^{a}$ Department of Civil Engineering, L.E.E.G.O, University of Houari Boumedien (USTHB), Algiers, Algeria \\ ${ }^{\mathrm{b}}$ Department of engineering, CONSTRUCT-GEO, (FEUP), University of Porto, Portugal \\ Received 29 April 2019; received in revised form 7 October 2019; accepted 9 October 2019
}

\begin{abstract}
This article addresses the results of an experimental study on the behavior of soil; this soil was exposed to long-term treatment with lime and numerous wetting-drying cycles. This research investigated the effect of a wide range of lime contents on the soil volume, soil water content evolution and durability (unconfined compressive strength (UCS), plasticity index (PI) and cation exchange capacity (CEC)) for stabilized soil in contact with water. This experimental study was performed on soil treated with lime (varying from no lime to $8 \%$ ) corresponding to three levels of improvement: soil improvement only, stabilization and insensitivity to water, and long-term stabilization during wetting-drying cycles. The results indicated that the UCS increases, PI and CEC decreases with the lime level. For lime levels above 4\%, the behavior of the treated soil under wetting-drying was satisfactory. Mineralogical analyses indicated that the formation of calcium silicate hydrate C-S-H, ettringite C-S-A-H is responsible for the increased or decreased strength of the treated soil. $\mathrm{CaO}, \mathrm{SiO}_{2}$ and $\mathrm{Al}_{2} \mathrm{O}_{3}$ were three important minerals responsible for the increase or decrease in soil sample stabilization. Simple model executed in JMP statistical software was proposed and validated. We note that $\mathrm{CaO}$ and $\mathrm{SiO}_{2}$ have the most influential effects by very low values of probability for the responses studied, which confirms the hypothesis of that these models can be used to model UCS and PI in curing time and wetting-drying cycles.
\end{abstract}

Keywords: Soil; Lime; Treatment; Wetting; Drying cycles; Long term

\section{Introduction}

The technique of soil treatment is a sustainable and ecological method within the field of earthworks, in the construction of road embankments and other construction practices in regions with regular and extreme soil conditions (foundations, railways, highways, roads, etc.) [1-3]. Freezing-thawing [4,5] and wettingdrying cycling [6-8] is one of the most destructive phenomena with regard to infrastructure damage. However, the results of some research on the effects of wetting-drying cycles on the stability and durability of soils depend on the percentage of stabilizer, test methods, the type of soil, and the cure conditions used [9-11]. The addition of lime has an immediate effect on the agglomeration and flocculation of clay particles due to cation exchange on the surface of soil particles. The result of this reaction in the short term is mainly to improve the plasticity and workability of soil [12-14]. In the long term, this reaction results in the formation of cementitious C-S-H and C-S-A-H materials [15]. Cement and lime could hydrate normally in clay minerals, is mainly produced by hydrated calcium silicate $\mathrm{C}-\mathrm{S}-\mathrm{H}$ and $\mathrm{CH}$. The soil could absorb $\mathrm{CH}$ up to

\footnotetext{
* Corresponding author

E-mail address: maafinabil@ymail.com (M. Nabil).

Peer review under responsibility of Chinese Society of Pavement Engineering.
}

the point of saturation. Then, the pozzolanic reaction occurred between the remaining $\mathrm{CH}$ and the soil to generate a supplement of $\mathrm{C}-\mathrm{S}-\mathrm{H}$, determining the difference in strength between the treated soils $[16,17]$. In the case of (illite and kaolinite) consumed little $\mathrm{CH}, \mathrm{Ca}(\mathrm{OH})_{2}$ and $\mathrm{C}-\mathrm{S}-\mathrm{H}$ formed in the treated soil was higher, in contrary in the case of montmorillonite the amount of $\mathrm{CH}$ consumed is more, so the $\mathrm{Ca}(\mathrm{OH})_{2}$ and $\mathrm{C}-\mathrm{S}-\mathrm{H}$ formed was lower [18]. If the $\mathrm{CH}$ in treated soils can be under-saturated, the amount of $\mathrm{C}-\mathrm{S}-\mathrm{H}$ generated by the cement or lime decreases because of the additional consumption of $\mathrm{Ca}_{2}{ }^{+}$and $\mathrm{OH}^{-}$ions by the soil. This explains why an equal amount of binder would not produce an equal amount of hydrates in the treated soils [19].

Two approaches, experimental and modulatory, were used to analyze the influence of lime on compacted soil after long-term preservation and under wetting-drying cycles. The experimental approach aims to document the effect of lime on compact soil in terms of UCS and PI, as one of the most important parameters for the determination of soil-binder behavior, and to determine the appropriate dosages $[20,21]$.

The experimental design method is a mathematical approach to determine now the links between parameters can influence the phenomenon studied (named the factor) and the physical or mechanical magnitudes studied (named the response). This method also aims to elucidate the relationships between the 
response and the factors as well as the factors between them. Factors represent all controllable variables that may affect the observed response. The results are the magnitudes observed by each experiment performed. Statistical modeling confirms the proposed hypothesis concerning the influence of the chemical composition and lime on the behavior of a compacted soil treated with lime under long-term preservation and subjected to wettingdrying cycles; mathematical models for summer are drawn using the proposed experimental method.

Some research encourages the use of new methods and correlations considering the availability, price, and cost of transportation in the characterization and controls the strength of treated soil properties. These methods and relationship helps to choose the compaction effort and the quantity of lime to provide a mixture that meets the objective required at the optimum time and cost.

\section{Materials and testing methods}

\subsection{Materials}

Tables 1 and 2 presented the physical-chemical properties of the studied soil: Atterberg limits [22], Methylene blue value [23], Clay content [24], pH [25] and Free swelling [26]. The studied soil was collected from the region of M'Sila, northern Algeria and rated CH soil according classification (Unified Soil Classification System) [27]. Fig. 1(a) presented the results of the untreated soil X-ray diffractogram. This soil mainly includes smectite, kaolinite, illite, quartz and chlorite.

The lime used for the treatment of soil is quicklime $(\mathrm{CaO})$, and Table 3 presented the physical and chemical characteristics of the lime used.

\subsection{Sample preparation}

Natural soil was initially dried for two days at $60^{\circ} \mathrm{C}$ before being pulverized and passed through a $4.75 \mathrm{~mm}$ sieve. The drying method followed in our work is based on ASTM D2216 [28], and we verified that all of the water evaporated by measuring the change in weight of soil until a variation equal to $1 / 1000$ was observed. The treated soil was meticulously mixed with a predetermined quantity of lime in a dry state until the mixture had a uniform and homogeneous appearance. Water was then added to the mixture, which was remixed thoroughly. The wet mixture was then placed in plastic bags and rested for 24 hours for untreated soil and 1 hour for treated soil to allow for mellowing. Finally, the studied soils were compacted according to ASTM D-698 [29].

\subsection{Wetting-drying test}

Following 180 days of curing, the studied soils were exposed to several wetting-drying cycles in accordance with the ASTM D-

Table 1

Geotechnical properties of studied soil.

\begin{tabular}{ll}
\hline Parameters & Value \\
\hline Liquid limit & 60.9 \\
Plastic limit & 29.5 \\
Plasticity index & 31.4 \\
Methylene blue value & 6.2 \\
Grain size $>0.075 \mathrm{~mm}$ & 84.4 \\
Clay content & 44.9 \\
pH & 8.5 \\
Free swelling & 4 \\
classification(UCSC) & $\mathrm{CH}$ \\
\hline
\end{tabular}

Table 2

Chemical composition of studied soil and lime.

\begin{tabular}{llllllllll}
\hline Constituents \% & $\mathrm{SiO}_{2}$ & $\mathrm{Al}_{2} \mathrm{O}_{3}$ & $\mathrm{Fe}_{2} \mathrm{O}_{3}$ & $\mathrm{CaO}$ & $\mathrm{MgO}$ & $\mathrm{K}_{2} \mathrm{O}$ & $\mathrm{Na}_{2} \mathrm{O}$ & $\mathrm{SO}_{3}$ & $\mathrm{Cl}$ \\
\hline Soil & 50.01 & 15.81 & 6.76 & 8.39 & 2.42 & 1.57 & 0.5 & 3.31 & 0.03 \\
Quicklime & 1.35 & 3.27 & 0.87 & 82.77 & 1.83 & 0.151 & 0.064 & 0.11 & - \\
\hline
\end{tabular}

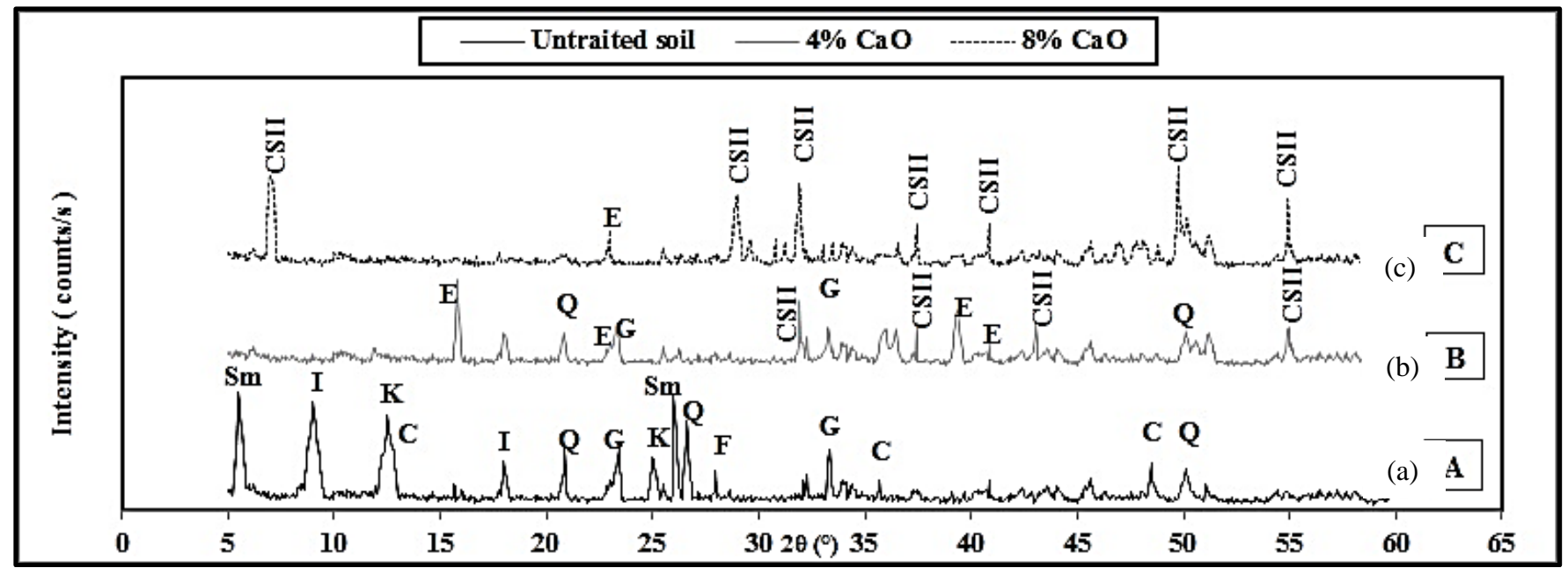

Fig. 1. XRD patterns of soil (a) untreated soil, (b) soil with $4 \%$ of lime and exposed to wetting- drying after 180 days, (c) s+oil with $8 \%$ of lime and exposed to wetting-drying after 180 days.

(I: illite, K: kaolinite, C: chlorite, Sm: Smectite and Q: quartz) 
Table 3

Physical properties of quicklime.

\begin{tabular}{ll}
\hline Properties & Value \\
\hline Bulk Density & $731 \mathrm{~g} / \mathrm{l}$ \\
Density & $3.315 \mathrm{~g} / \mathrm{cm}^{3}$ \\
Absorption coefficient & $<5 \%$ \\
Sensitivity to freezing b30 & $<30 \%$ \\
Volume of extinction & $2.73 \mathrm{~cm}^{3}$ \\
Over $630 \mu \mathrm{m}$ & $0 \%$ \\
Over $90 \mu \mathrm{m}$ & $<10 \%$ \\
\hline
\end{tabular}

559 procedure [30]. In this study, 12 wetting-drying cycles were applied to the treated and untreated soils. Each cycle comprised 5 hours wetting by immersing in the water at a room temperature $\left(20^{\circ} \mathrm{C}\right)$ and then oven drying at $60^{\circ} \mathrm{C}$ for another 42 hours. The drying temperature was maintained at $60^{\circ} \mathrm{C}$, and the water content was recorded at the end of each cycle. The change in volume was measured by the variation in the height and diameter of the soil.

\subsection{Unconfined compressive strength}

All stabilized soils were cured for 180 days at a constant temperature of $20^{\circ} \mathrm{C}$. The UCS was determined according to the ASTM procedure [31]. The load was applied to the soil samples at a rate of $0.1 \mathrm{~mm} / \mathrm{min}$, a process that continued until the failure of samples occurred. For the treated soil, the UCS was determined at the end of each wetting-drying cycle.

\subsection{Cation exchange capacity (CEC)}

The study of the influence of CEC on the strength of the treated soil is done by analysis of the $\mathrm{CH}$ saturation in interstitial solution (the ratio of $\mathrm{CH}$ concentration in the interstitial solution to the saturation is expressed by saturated index (SI) in this study). CEC of treated soil was performed on the basis of standard soil CEC (sodium acetate) [32] with the procedures: (1) takes $4 \mathrm{~g}$ of air-dried soil and placed in a centrifuge tube; (2) add $33 \mathrm{ml}$ of sodium acetate solution $(1 \mathrm{~mol} / \mathrm{L})$, then the tube was vibrated for 5 minutes; (3) the centrifuge was operated for 5 minutes at a speed of $4000 \mathrm{r} / \mathrm{min}$; (4) added $25 \mathrm{ml}$ of isopropyl alcohol $(99 \%$ of purity), which was then vibrated for 5 minutes at a speed of 4000 $\mathrm{r} / \mathrm{min}$; (5) add $25 \mathrm{ml}$ of ammonium acetate ( $1 \mathrm{~mol} / \mathrm{L}$ ), then vibrate for $5 \mathrm{~min}$ at a speed of $4000 \mathrm{r} / \mathrm{min}$; (6) after transfer the solution into volumetric flask $(100 \mathrm{ml})$; (7) add a solution of ammonium acetate $(1 \mathrm{~mol} / \mathrm{L})$ to the volumetric flask until the volume of the solution reaches $100 \mathrm{ml}$, after using atomic absorption spectrometry measures the concentration of $\mathrm{Na}^{+}$in the solution in the volumetric flask.

Excess sodium acetate and isopropylique solution in the centrifuge tube was removed;

The value of the CEC was calculated according to the formula:

$C E C=\frac{c V}{23 \mathrm{mk} * 10}$

where, $V$ : volume of the volumetric flask, $m$ : mass of the soil sample, $c$ is the concentration of $\mathrm{Na}^{+}$in the solution in the volumetric flask, $K$ is the transformed soil coefficient of the air dried in a drying oven, in this study $K$ equals 0.85 .

The concentration of some major ions in the pore solution was measured based on the standard soil test method [33]. The main methods of analysis are as follows: $[\mathrm{OH}]$ was determined with hydrochloric acid titration solution through a methyl red indicator, $\left[\mathrm{K}^{+}\right]$and $\left[\mathrm{Na}^{+}\right]$were determined with flame photometry, atomic absorption spectrometry was determined the $\left[\mathrm{Ca}^{2+}\right]$, and $\left[\mathrm{Al}^{3+}\right],\left[\mathrm{SO}_{4}{ }^{2-}\right]$ was determined with barium sulfate gravimetry. Silicon-molybdenum blue colorimetry was determined $\left[\mathrm{SiO}_{4}{ }^{4-}\right]$.

According to ionic equation $\mathrm{Ca}(\mathrm{OH})_{2}=\mathrm{Ca} 2^{+}+2 \mathrm{OH}^{-}$the product of ionic activity IAP $\left(\mathrm{IAP}=\left[\mathrm{Ca} 2^{+}\right][\mathrm{OH}-]_{2}\right)$ is calculated. After SI of solution was calculated as follows by Eq. (1), in $K s p$ is the thermodynamic solubility product constant of $\mathrm{CH}$ at $25^{\circ} \mathrm{C}$

$S I=\log \frac{I A P}{K s p}$

The value of $K s p$ used in this paper is $6.3096 \times 10^{-6}$.

$\mathrm{SI}<0$ means that $\mathrm{CH}$ is under-saturated; $\mathrm{SI}=0$ means that the $\mathrm{CH}$ is just saturated in the pore solution; $\mathrm{SI}>0$ means that $\mathrm{CH}$ is supersaturated.

\section{Experimental results}

\subsection{Effect of lime content on compaction parameters}

Table 4 shows the variation of the maximum dry density and the optimum water content values for soil treated with lime obtained in the normal proctor compaction tests. It is clear that these parameters are strongly influenced by lime content. When the lime content passed from 0 to $8 \%$ the optimal moisture content increased with $27 \%$ due to exothermic reaction between lime and water which requires an extra amount of water to achieve a satisfactory compactness in a relatively wet state. As a consequence, the workability of the treated soil becomes easier when compared with the untreated soil. However the maximum dry density of treated soil shows the opposite behavior, they show inversely proportional relation to the lime content. The maximum compactness becomes less, which leads to a reduced in the maximum dry density compared to the untreated soils with higher level of optimum moisture content. That explains the decrease of maximum dry density by the reorganization of clay particles caused via the phenomenon of flocculation / aggregation.

\subsection{Unconfined compressive strength}

Fig. 2 presented the evolution of UCS of the treated soil with different lime dosages at different curing periods. Addition of lime causes the increasing of UCS for treated soils in comparison with untreated soils; we notice a proportional relationship with the UCS and dosage of lime. In the short term ( 28 days of curing), the mechanical strength of treated soil shows minor improving, compressive strength sees its value multiplied 3 times greater ( 0.337 to $1.182 \mathrm{MPa})$. When the cure is extended, UCS of treated

Table 4

Optimum Water content (OWC) and max dry unit weight of studied soils.

\begin{tabular}{lll}
\hline $\begin{array}{l}\text { Lime content } \\
(\%)\end{array}$ & $\begin{array}{l}\text { Optimal dry unit weight } \rho d \\
\left(\mathrm{kN} / \mathrm{m}^{3}\right)\end{array}$ & $\begin{array}{l}\text { OWC } \\
(\%)\end{array}$ \\
\hline $0 \%$ & 15.16 & 22.8 \\
$2 \%$ & 14.8 & 23.1 \\
$4 \%$ & 14.43 & 25.4 \\
$6 \%$ & 14.07 & 27.2 \\
$8 \%$ & 13.46 & 31.1 \\
\hline
\end{tabular}




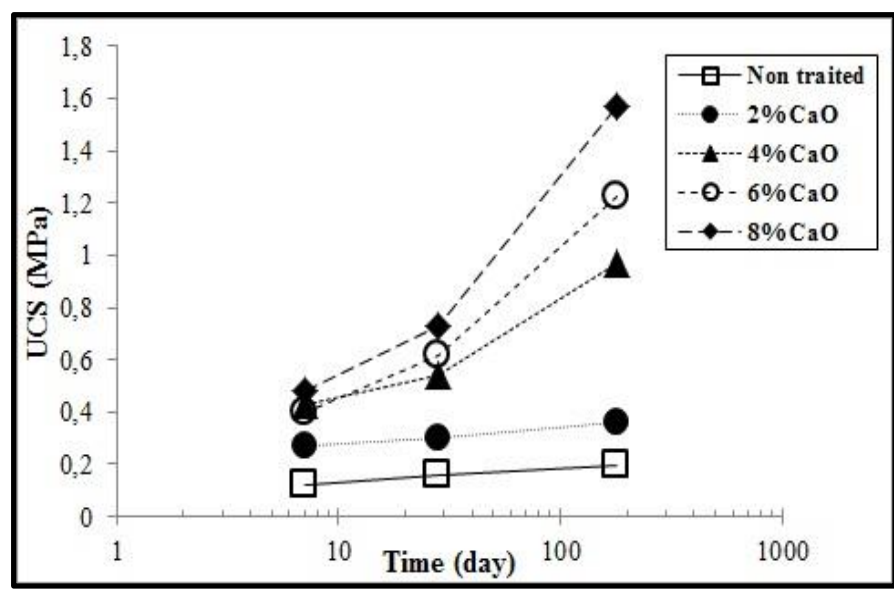

Fig. 2. Unconfined compressive strength with curing times of the treated soil.

soil to the lowest dosages slightly changes for soil treated at $4 \%$ of lime. For a higher dosage, UCS evolves positively and stands out gradually according to dual parameters; dosage of lime and time of curing. Hence, at long time of curing, treated soil with $8 \%$ of lime, this sees its UCS value multiplied by 5 times after 180 days of curing, to achieve the higher values of $2.885 \mathrm{MPa}$. This behavior is corroborated by several authors [34-38]. This increase in strength translates the reaction between soil and lime, the consequence of this reaction is the formation of C-S-H and C-SA-H [20].

\subsection{Wetting-drying cycle results}

Table 5 presented the variation in the volume of the studied soils after 180 days of curing and exposure to wetting-drying cycles. The increase in the number of wetting-drying cycles significantly affected the variation in the volume of the studied soils; we observed a decrease in volume for all the studied soils. Untreated soil and soil with $2 \%$ lime presented substantial damage during the $1^{\text {st }}$ cycle, and treated soil with $4 \%$ lime presented substantial damage during the $6^{\text {th }}$ cycle (approximately $70.21 \%$ ). However, soils treated with $8 \%$ lime presented favorable behavior during wetting-drying cycles, with a loss in volume of approximately $9.23 \%$.

The variations in water content showed an increase after each cycle for soils treated with $4 \%$ lime. The water content remained almost stable after the $7^{\text {th }}$ cycle for soil treated with levels of lime higher than 4\%. It can be observed that the water content decreases when the lime content increases. Soil is a porous material, so the ability to absorb water by capillary action is high [6]. Cracks occur, causing a loss of strength and then an acceleration of soil degradation. The use of lime in the soil decreases and reduces crack propagation by forming new hydrates by pozzolanic reaction [8]. The pozzolanic reactions are the result of the combination of the silica and the alumina of the soil $\mathrm{SiO}_{2}, \mathrm{Al}_{2} \mathrm{O}_{3}$ with lime calcium $\mathrm{CaO}$ in the presence of water. These reactions result in the formation of calcium hydrates due to the presence of $\mathrm{Ca}^{+2}, \mathrm{OH}^{-}$and $\mathrm{SiO}_{4}$ and $\mathrm{Al}_{2} \mathrm{O}_{6}$ ions $[6,15]$. Figs. 1(b) and 1(c) presented an XRD analysis of the treated soil, showing the formation of calcium hydrates C-S-H, C-A-H and C-A-S-H appeared in treated soil with low lime content only. The highest concentration of ettringite was detected in treated soil with $4 \%$ lime. This is attributed to more reactions occurring between the gypsum and lime during wettingdrying cycles. The effect of the lime addition is visible in soils cured for 180 days, for which the water content almost stabilizes.

\subsection{Unconfined compressive strength vs wetting-drying cycles}

The UCS of treated soil decreased with the increased in the number of wetting-drying cycles, as shown in Fig. 3(a). The largest reduction was recorded after the $1^{\text {st }}$ cycle for the tested soil in the wetting state, and the reduction gradually reached minimum values in the $6^{\text {th }}$ cycle for the treated soil with $4 \%$ lime after 180 days of curing. Untreated soil and soil treated with $2 \%$ of lime deteriorated in the $1^{\text {st }}$ cycle. The UCS value of the tested soil under drying conditions was superior to that under wetting conditions. The maximum values of UCS were obtained for the soil treated with $6 \%$ and $8 \%$ lime (relative to the soil treated with less lime). These results show that lime content affects the sustainability of soil properties. In the wetting state, the UCS values of the treated soil after 180 days of curing declined by $54 \%$ for $4 \%$ lime in the $6^{\text {th }}$ cycle and $42 \%$ for $8 \%$ lime in the $12^{\text {th }}$ cycle, among all the cycles. In the drying state, the UCS values were inferior to those in the

Table 5

Loss of volume and water content changes with wetting and drying cycles of studied soils.

\begin{tabular}{|c|c|c|c|c|c|c|c|c|c|c|}
\hline & $0 \%$ & & $2 \%$ & & $4 \%$ & & $6 \%$ & & $8 \%$ & \\
\hline $\begin{array}{l}\text { Number } \\
\text { of cycles } \\
\text { of cycles }\end{array}$ & $\begin{array}{l}\text { Loss } \\
\text { volume } \\
(\%)\end{array}$ & $\begin{array}{l}\text { water } \\
\text { content } \\
(\%)\end{array}$ & $\begin{array}{l}\text { Loss } \\
\text { volume } \\
(\%)\end{array}$ & $\begin{array}{l}\text { water } \\
\text { content } \\
(\%)\end{array}$ & $\begin{array}{l}\text { Loss } \\
\text { volume } \\
(\%)\end{array}$ & $\begin{array}{l}\text { water } \\
\text { content } \\
(\%)\end{array}$ & $\begin{array}{l}\text { Loss } \\
\text { volume } \\
(\%)\end{array}$ & $\begin{array}{l}\text { water } \\
\text { content } \\
(\%)\end{array}$ & $\begin{array}{l}\text { Loss } \\
\text { volume } \\
(\%)\end{array}$ & $\begin{array}{l}\text { water } \\
\text { content } \\
(\%)\end{array}$ \\
\hline 0 & 0 & 0 & 0 & 0 & 0 & 0 & 0 & 0 & 0 & 0 \\
\hline 1 & -100 & 22.6 & -100 & 21.12 & 6.624 & 2.697 & 0.364 & 3.056 & 0.784 & 1.937 \\
\hline 2 & & & & & 12.634 & 7.897 & 0.059 & 6.367 & 0.625 & 3.657 \\
\hline 3 & & & & & 22.15 & 11.641 & 1.265 & 9.359 & 0.667 & 4.681 \\
\hline 4 & & & & & 38.624 & 14.897 & 4.512 & 11.877 & 1.023 & 5.07 \\
\hline 5 & & & & & 55.624 & 17.897 & 5.689 & 14.256 & 1.514 & 5.631 \\
\hline 6 & & & & & 70.215 & 18.697 & 8.659 & 15.256 & 2.635 & 5.937 \\
\hline 7 & & & & & & & 10.519 & 14.589 & 3.621 & 6.631 \\
\hline 8 & & & & & & & 11.846 & 13.056 & 5.512 & 6.928 \\
\hline 9 & & & & & & & 13.225 & 14.249 & 6.524 & 6.985 \\
\hline 10 & & & & & & & 16.611 & 13.733 & 8.541 & 7.04 \\
\hline 11 & & & & & & & 17.292 & 13.79 & 9.635 & 6.373 \\
\hline 12 & & & & & & & 19.624 & 13.619 & 9.231 & 6.542 \\
\hline
\end{tabular}


initial state for treated soil with a low percentage of lime. For treated soil with high percentages of lime, we observed high UCS values at the end of 12 cycles and higher UCS values that those obtained in the initial drying state $[7,20]$.

\subsection{Strength improvement factors (UWD):}

Figs. 3(b) and 4 shown the strength coefficient (UWD) of soils treated with lime after 12 wetting-drying cycles. The UWD a nondimensional parameter is introduced as explained below equation (3) by the ratio of the simple compressive strength that has undergone 12 cycles of wetting-drying $\left(\mathrm{UCS}_{12}\right)$ and the simple compressive strength that were not subjected to these solicitation, but preserved in water during this time (UCS):

$\mathrm{UWD}=\frac{\mathrm{UCS} 12 \text { at } \mathrm{n} \text { day }}{\mathrm{UCS} \text { at } \mathrm{n} \text { day }} * 100$

The UCS of treated soil with 0 and $2 \%$ of lime has very low $\mathrm{UCS}_{12}$ and do not change over time (UCS $\left.=0.695-0.922 \mathrm{MPa}\right)$. After $12^{\text {th }}$ wetting-drying cycles, the treated soil is destroyed and completely lose their strength (UWD $=0 \%$ ). In treated soil with $4 \%$ of lime, UCS increase slowly over time: UCS $=1.063 \mathrm{MPa}$ at 180 days of cure. The treated soil with $4 \%$ destroyed after the $6^{\text {th }}$ cycles for 180 days of cure $\left(\mathrm{UCS}_{12}\right.$ and UWD $\left.=0 \%\right)$. Remember the problem for soil treated with lime the mechanical performance change very slowly over time cure. After compaction, the treated soil consists of large aggregates dispersing and creating macropores between the aggregates, with several lime nodules not in intimate contact with the aggregates but concentrating heterogeneously in the mixture. The mechanical performances of treated soil at 6 and $8 \%$ develop with the cure time $(\mathrm{UCS}=1.912$ and $2.889 \mathrm{MPa}$ à 180 days. Their UWD increased in a very modest way: from $4 \%$ at 7 days to $25 \%$ at 180 days of cure for the soil treated with $6 \%$ lime, and $10 \%$ at 7 days to $40 \%$ at 180 days of cure for the treated soil with $8 \%$ lime.

\subsection{Pore size analysis}

Untreated soil has a trimodal pore structure: micropores (natural intraaggregated pores) centered at $0.04 \mu \mathrm{m}$, the proportion of micropores $(<0.3 \mu \mathrm{m})$ of the treated soil is greater than the untreated soil, this family of pores is not modified during the curing time. The treated soil with 4 and $8 \%$ of lime also contains macropores of a size $(>6 \mu \mathrm{m})$ (artificial interaggregated pores); this size range is lower than the untreated soil (macropores centered at $20 \mu \mathrm{m}$ and macropores centered at $200 \mu \mathrm{m})$. This family of pores remains stable over time illustrated in Fig. 5.

Wetting-drying cycles led to an increasing in macropores due to additional ettringite formation. A slight reduction in micropores volume can also be observed and the pore size of the treated soil appears to be less affected by wetting-drying cycles than the untreated soil. In general, when the lime dosage increases, the pore volume and the porosities decrease, as shown in Fig. 5. These two parameters also increase with wetting-drying cycles in low lime content, indicating the poor durability of these soils against these conditions.

Quantitative analysis of microstructure for treated and untreated soil can be established, calculating the void index of the three pore families are then defined: micropores $(0.0072 \mu \mathrm{m}-0.3 \mu \mathrm{m})$, mesopores $(0.3 \mu \mathrm{m}-6 \mu \mathrm{m})$, macropores $(>6 \mu \mathrm{m})$ are showing in Fig. 6.
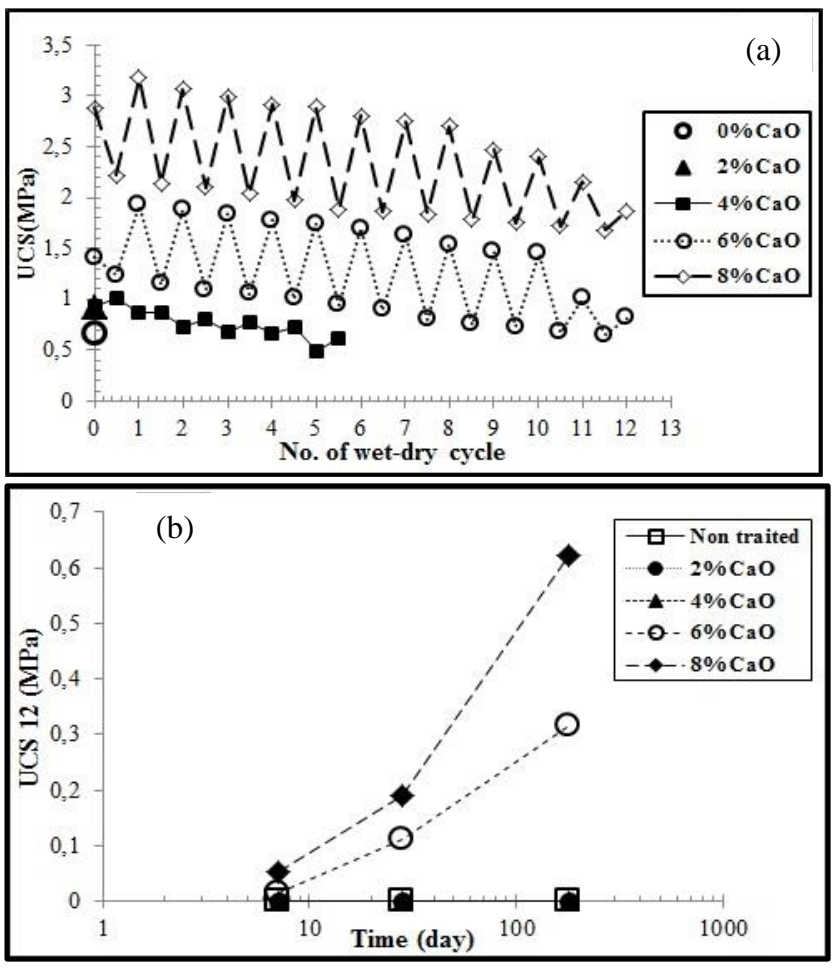

Fig. 3. UCS vs wetting-drying cycles (a) after 180 days of curing, and (b) after 7, 28 and 180 days.

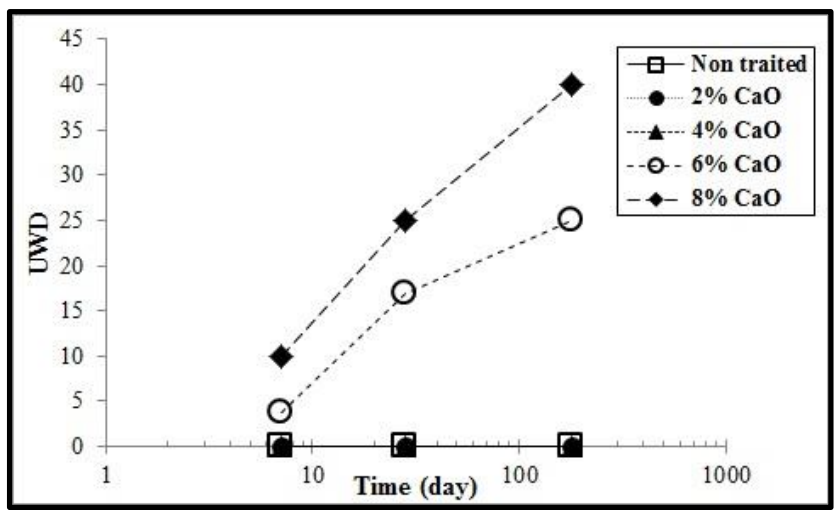

Fig. 4. Strength coefficient of soils treated with lime after 12 wetting-drying cycles.

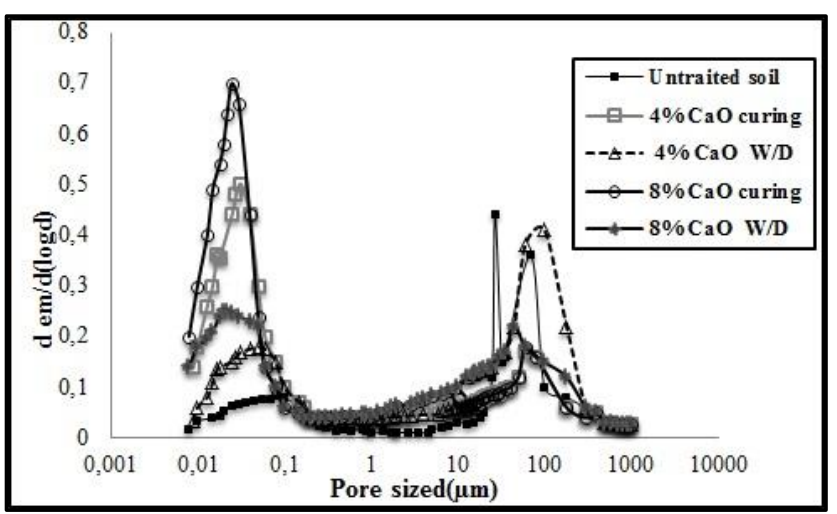

Fig. 5. Pore size distribution of the soil samples with curing times and the end of wetting-drying cycles after 180 days curing. 


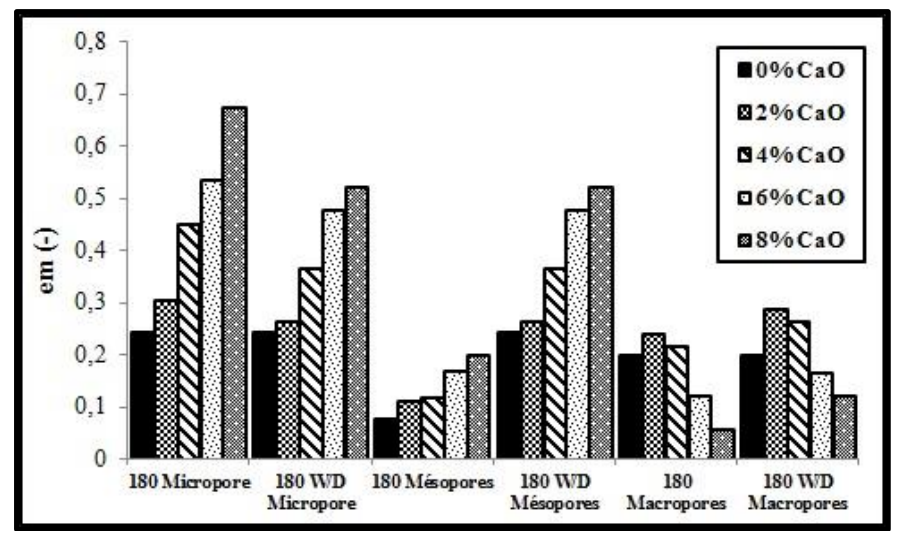

Fig. 6. Quantitative analysis of the microstructure for treated and untreated soil after 180 days of curing exposed to wetting drying cycles.

Void index micropores of soil treated is greater than untreated soil, which is positively correlated with lime dosage and cure time. Evolution of void index of micropores is similar to the evolution of mechanical performances in two cure modes. The evolution of micropores is explained by the effect of treatment which leads to the formation of cementitious products during the pozzolanic reactions. The amount of mesopores (natural inter-aggregate pore) of treated soil is superior to untreated soil; this phenomenon is explained by flocculation during incorporation of lime in the soil. The creation of agglomeration aggregates is consecutive to flocculation, leads to a reorganization of the internal structure of soil after treatment, and is the origin of the higher proportion of mesopores (natural inter-aggregate pore) in treated soil compared to untreated soil.

Untreated soil has more macropores (artificial inter-aggregate pore) in comparison to treated soil; reduction of macropores for treated soils compared to untreated soil is also explained by the phenomenon of immediate flocculation after the addition of lime in the soil, and by the initial condition of compaction of treated soils with lower densities. Over time, for 6 and $8 \%$ of lime content, the formation of cementitious causes the decrease in macropores.

\subsection{Effect of CEC in strength of treated soil}

$\mathrm{C}-\mathrm{S}-\mathrm{H}$ is the main contributor to strength, while $\mathrm{CH}$ has no direct contribution to the strength of treated soil. The production of C-S$\mathrm{H}$ in the treated soil was determined by the concentration of $\mathrm{Ca}^{+}$

Table6

Concentration of main ions in pore solutions and SI of treated soil and $\mathrm{OH}^{-}$ions in the interstitial solution when the $\mathrm{CH}$ concentration was under-saturated [39].

When the concentration of $\mathrm{CH}$ in the interstitial solution of the treated soil is insufficiently saturated, the production of C-S-H and the strength of the treated soil are low.

In case of treated soils with $(0,2$ and $4 \%)$ of lime at curing time and wetting-drying cycle, the $\mathrm{Ca}^{2+}$ ions and $\mathrm{OH}^{-}$is low showing in the Table 6. The concentration of $\mathrm{Ca}^{2+}$ and $\mathrm{OH}^{-}$in the interstitial solution increases as the percentage of lime increases, which improves the strength of treated soil because of the increased production of C-S-H. So C-S-H can be fully produced in the treated soil when $\mathrm{CH}$ in the pore solution is saturated, and the strength reaches its maximum. These indicate that the strength of treated soil decreases with increasing CEC in the sample. If the $\mathrm{CEC}$ is too high (montmorillonite content in bentonite is higher) the $\mathrm{Ca}^{2+}$ ions consume by an additional exchange of cations that should be used originally to generate silicate calcium hydrate C-S$\mathrm{H}$, this would result in low strength of treated soil.

\subsection{Atterberg limits}

Figs. 7(a) and 7(b) presents the variation in the Atterberg limits for the treated and untreated soil. This index is the measure of the cohesion qualities that result from the clay content. The PI is merely an indicator of the amount of water that should be added to change the moisture of the soil from its PL to LL. The reduction in the PI occurs in concomitance with the reduction in water content in the studied soils. After treatment, the soil presents a state under the new PL, that is to say, the soil was transformed from a plastic state (deformable-sticky) before treatment to a solid state (rigidfragile) after treatment. Therefore, this facilitates the implementation of the embankment (movement of machines). We notice an increasing of PL about $37.64 \%$ between treated and untreated soil with $8 \%$ of lime, without any significant change in LL. Consequently, there is a decrease in PI of soils, we notice a reduction about $51.28 \%$ between treated and untreated soil with $8 \%$ of lime. The results also show that the additions of lime in the soil exposed to wetting-drying cycles are very efficient within the Atterberg limits of the studied soil. Based on the USCS classification, the $\mathrm{CH}$ soil (flat clay) was changed to $\mathrm{MH}$ soil (elastic silt) after the $1^{\text {st }}$ wetting-drying cycle (Fig. 7(b)) for soil with $6 \%$ and $8 \%$ lime. However, the PL increase by approximately $35.56 \%$ and $39.03 \%$ and the LL decrease by approximately $16.98 \%$ and $16.89 \%$ after the $12^{\text {th }}$ wetting-drying cycle for soils with $6 \%$ and $8 \%$ lime conserved for 180 days, respectively $[39,40]$.

\begin{tabular}{|c|c|c|c|c|c|c|c|c|c|c|}
\hline \multirow[b]{2}{*}{ Lime $(\%)$} & \multicolumn{10}{|c|}{ Concentration $\left(\mathrm{mmol} \mathrm{L}^{-1}\right)$} \\
\hline & & $\mathrm{Na}^{+}$ & $\mathrm{K}^{+}$ & $\mathrm{Ca}^{2+}$ & $\mathrm{OH}^{-}$ & $\mathrm{Al}^{3+}$ & $\mathrm{SO}_{4}^{2-}$ & $\mathrm{Si}^{4+}$ & SI & \\
\hline $0 \%$ & Curing & 9.897 & 2.111 & 0.455 & 100.310 & 1.887 & 0.525 & 0.461 & -0.246 & under-saturated \\
\hline $0 \%$ & W/D & 9.145 & 2.222 & 0.313 & 91.570 & 2.221 & 0.522 & 0.412 & -0.411 & under-saturated \\
\hline $2 \%$ & Curing & 9.325 & 1.821 & 0.341 & 92.340 & 2.076 & 0.777 & 0.441 & -0.195 & under-saturated \\
\hline $2 \%$ & $\mathrm{~W} / \mathrm{D}$ & 9.987 & 2.111 & 0.535 & 103.410 & 1.887 & 0.564 & 0.432 & -0.245 & under-saturated \\
\hline $4 \%$ & Curing & 28.131 & 7.922 & 0.959 & 131.360 & 1.725 & 0.854 & 0.532 & -0.035 & under-saturated \\
\hline $4 \%$ & $\mathrm{~W} / \mathrm{D}$ & 57.912 & 27.660 & 1.542 & 117.560 & 2.176 & 0.367 & 0.671 & -0.048 & under-saturated \\
\hline $6 \%$ & Curing & 31.416 & 8.409 & 1.866 & 168.010 & 2.178 & 0.872 & 0.681 & 0.046 & supersaturated \\
\hline $6 \%$ & $\mathrm{~W} / \mathrm{D}$ & 30.716 & 11.321 & 2.118 & 153.540 & 1.977 & 0.843 & 0.591 & 0.039 & supersaturated \\
\hline $8 \%$ & Curing & 11.276 & 2.689 & 2.414 & 189.840 & 2.332 & 0.743 & 0.532 & 0.052 & supersaturated \\
\hline $8 \%$ & W/D & 31.476 & 8.709 & 1.966 & 168.010 & 2.178 & 0.732 & 0.731 & 0.044 & supersaturated \\
\hline
\end{tabular}




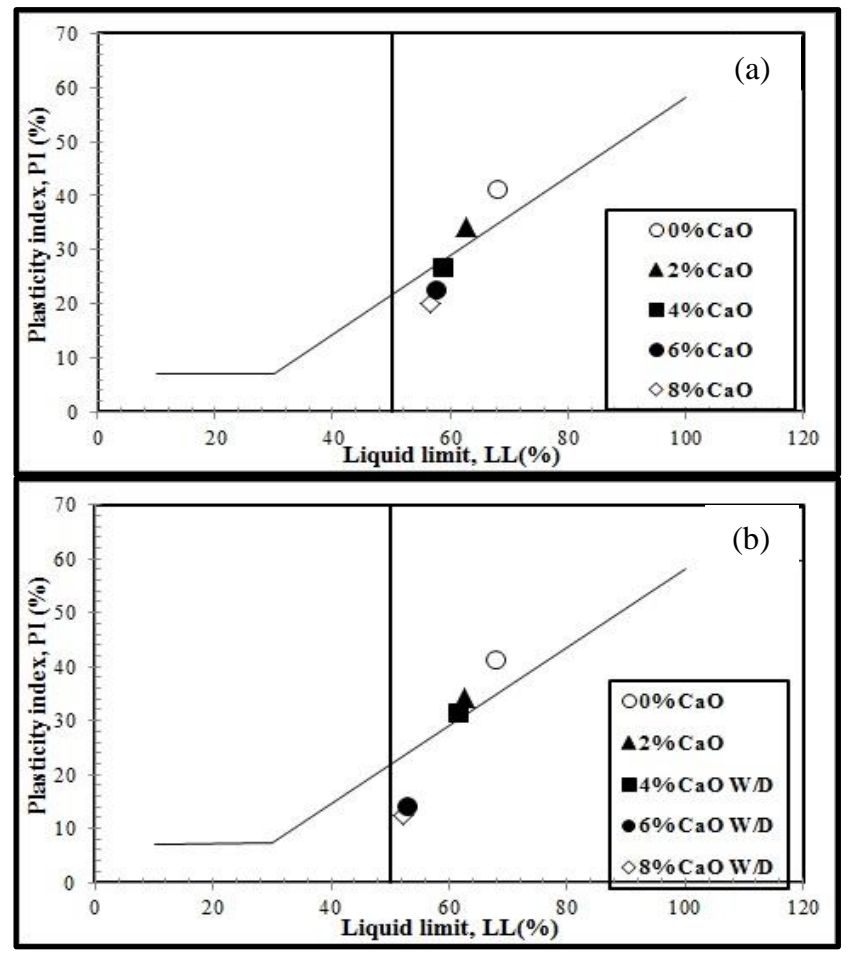

Fig. 7. Plasticity index for treated and untreated soil (a) after curing time and (b) at the end of wetting-drying cycles.

\subsection{UCS and PI relationship with the chemical compositions of the studied soils}

The variance analysis technique makes it possible to judge whether the effects calculated are significant. In general, in regression, the principle of variance analysis is to subdivide the total variation into a factorial component relative to the regression equation, or the model used, and a residual component, the first to be tested against the second.

Tables 7 and 8 show the variance analysis and coefficient estimates. We obtain very low values of Prob for the four responses studied $(0.0009,0.001,0.0336$ and 0.001$)$, less than 0.05 , which confirms the hypothesis of that these models can be used to model UCS and PI in wetting-drying cycles. According to the table of the effects of the analysis including the four models, it is clear that at least one effect has a strong influence on the response except for UCS in curing time, for which no effect is significant (Prob value $>|\mathrm{t}|$ greater than 0.05 ).

Indeed, we note that $\mathrm{CaO}$ and $\mathrm{SiO}_{2}$ have the most influential effects on curing time (PI) $(0.0335,0.0193)$. For wetting-drying cycles (UCS and PI), the $(\mathrm{CaO})$ shows the greatest influence on both responses $(0.0070,0.0002)$. The mathematical models of UCS, PI under curing time and wetting-drying cycles, according to $\mathrm{CaO}, \mathrm{SiO}_{2}$ and $\mathrm{Al}_{2} \mathrm{O}_{3}$, are determined by the following equations:

UCS prediction under curing time

$4,17683318037468 * \mathrm{CaO}+1,57860302488936 * \mathrm{SiO} 2-4,4692243505192 * \mathrm{~A} 12 \mathrm{O} 3$

PI prediction under cuiring time

$-53,605349673218 * \mathrm{CaO}+127,822345566525 * \mathrm{SiO} 2-203,11438298357 * \mathrm{Al} 2 \mathrm{O} 3$

UCS prediction under wetting-drying cycles

$5,78529281575254 * \mathrm{CaO}-7,2482335388241 * \mathrm{SiO}_{2}+19,5643094823151 * \mathrm{Al}_{2} \mathrm{O}_{3}$.

PI prediction under wetting-drying cycles

$-108,55996460092 * \mathrm{CaO}+111,164395268982 * \mathrm{SiO}_{2}-97,015495230513 * \mathrm{Al}_{2} \mathrm{O}_{3}$

Figs. 8 and 9 shows the mixing profiler, according to the analysis of two triangular UCS, PI diagrams for curing time and wettingdrying cycles. The variation is concentrated in the area between the values of $\left(0.5-0.9 \mathrm{SiO}_{2}\right),(0.1-0.5 \mathrm{CaO})$ and $\left(0.1-0.4 \mathrm{Al}_{2} \mathrm{O}_{3}\right)$.
Chemical analysis, UCS and PI in both cures shows that $\mathrm{CaO}$ varies between (10-30\%), $\mathrm{SiO}_{2}(50-70 \%), \mathrm{Al}_{2} \mathrm{O}_{3}(15-25 \%)$, UCS (0-3 MPa) and PI (10-45\%).

Table 7

Analysis of the variance

\begin{tabular}{|c|c|c|c|c|c|}
\hline & Source & Degrees of freedom & Sum of squares & Middle square F & F report \\
\hline \multirow[t]{3}{*}{ Curing time (UCS) } & Model & 3 & 15.400872 & 5.13362 & 11.1663 \\
\hline & residues & 12 & 5.516928 & 0.45974 & Prob. $>\mathrm{F}$ \\
\hline & Total & 15 & 20.917800 & & $0.0009 *$ \\
\hline \multirow[t]{3}{*}{ Curing time (PI) } & Model & 3 & 10694.008 & 3564.67 & 96.4718 \\
\hline & residues & 12 & 443.404 & 36.95 & Prob. $>\mathrm{F}$ \\
\hline & Total & 15 & 11137.413 & & $<.0001 *$ \\
\hline \multirow[t]{3}{*}{ Wetting-drying cycle (UCS) } & Model & 2 & 2.1864104 & 1.09321 & 4.5610 \\
\hline & residues & 12 & 2.8762060 & 0.23968 & Prob. $>\mathrm{F}$ \\
\hline & Total & 14 & 5.0626164 & & $0.0336^{*}$ \\
\hline \multirow[t]{3}{*}{ Wetting-drying cycle (PI) } & Model & 2 & 1428.3981 & 714.199 & 22.6975 \\
\hline & residues & 12 & 377.5920 & 31.466 & Prob. $>\mathrm{F}$ \\
\hline & Total & 14 & 1805.9901 & & $<.0001 *$ \\
\hline
\end{tabular}


Table 8

Coefficient estimates

\begin{tabular}{llllll}
\hline & $\mathrm{Term}$ & Estimation & Standard error & $\mathrm{t}$ ratio & Prob. $>|\mathrm{t}|$ \\
\hline Curing time (UCS) & $\mathrm{CaO}$ & 4.1768332 & 2.491656 & 1.68 & 0.1195 \\
& $\mathrm{SiO}_{2}$ & 1.578603 & 5.280233 & 0.30 & 0.7701 \\
& $\mathrm{Al}_{2} \mathrm{O}_{3}$ & -4.469224 & 17.45587 & -0.26 & 0.8023 \\
Curing time (PI) & $\mathrm{CaO}$ & -53.60535 & 22.33775 & -2.40 & $0.0335^{*}$ \\
& $\mathrm{SiO}_{2}$ & 127.82235 & 47.3374 & 2.70 & $0.0193 *$ \\
& $\mathrm{Al}_{2} \mathrm{O}_{3}$ & -203.1144 & 156.4923 & -1.30 & 0.2187 \\
Wetting-drying & $\mathrm{CaO}$ & 5.7852928 & 1.78159 & 3.25 & $0.0070^{*}$ \\
cycle (UCS) & $\mathrm{SiO}_{2}$ & -7.248234 & 5.778779 & -1.25 & 0.2336 \\
Wetting-drying & $\mathrm{Al}_{2} \mathrm{O}_{3}$ & 19.564309 & 17.70271 & 1.11 & 0.2908 \\
cycle (PI) & $\mathrm{CaO}^{\text {PI) }}$ & -108.56 & 20.41311 & -5.32 & $0.0002 *$ \\
& $\mathrm{SiO}_{2}$ & 111.1644 & 66.21212 & 1.68 & 0.1190 \\
& $\mathrm{Al}_{2} \mathrm{O}_{3}$ & -97.0155 & 202.8342 & -0.48 & 0.6410 \\
\hline
\end{tabular}

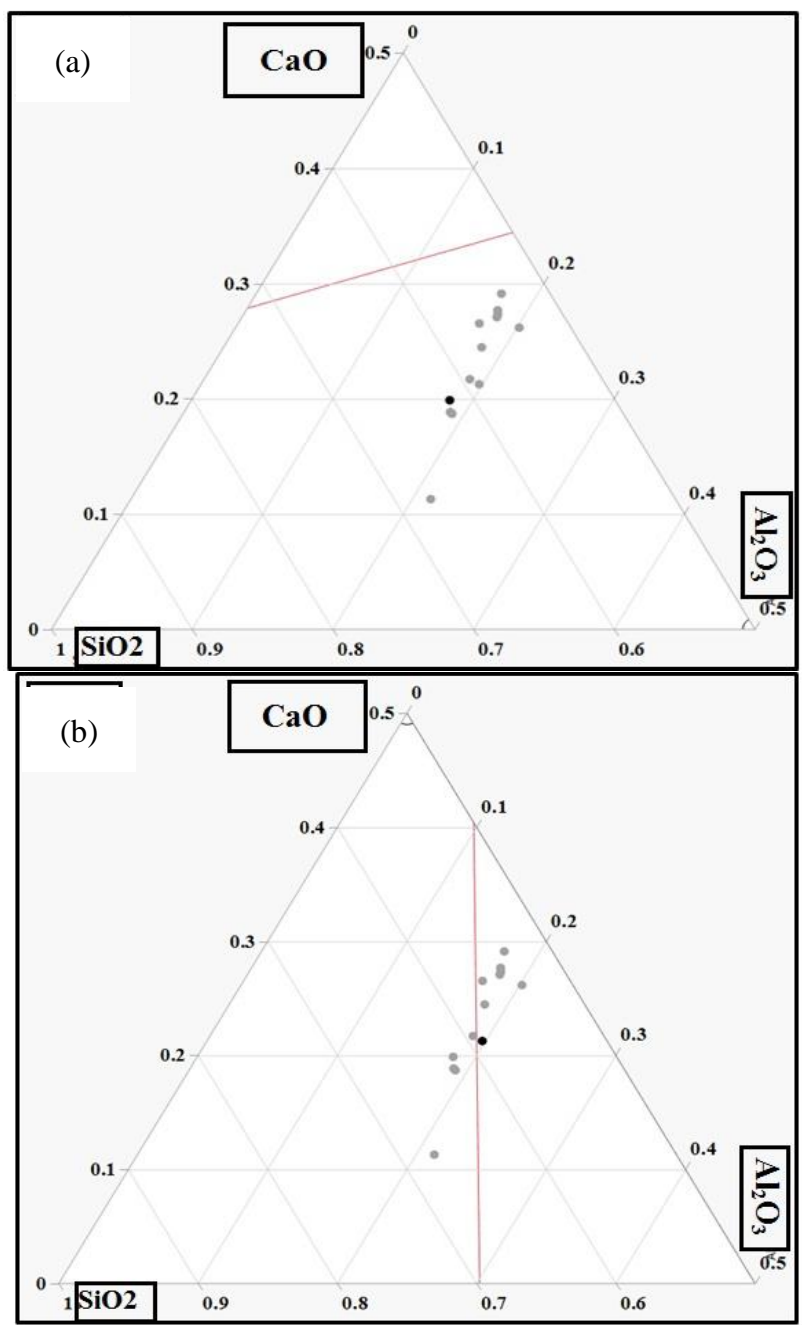

Fig. 8. Mixing profiler for treated and untreated soil (a) unconfined compressive strength and (b) plasticity index at the curing time.

\section{Conclusions}

The object of this work is to provide some answers concerning the influence of lime treatment at variable dosages; the physical, chemical, and mechanical strength of treated soils to wettingdrying cycles and some conclusions were drawn.

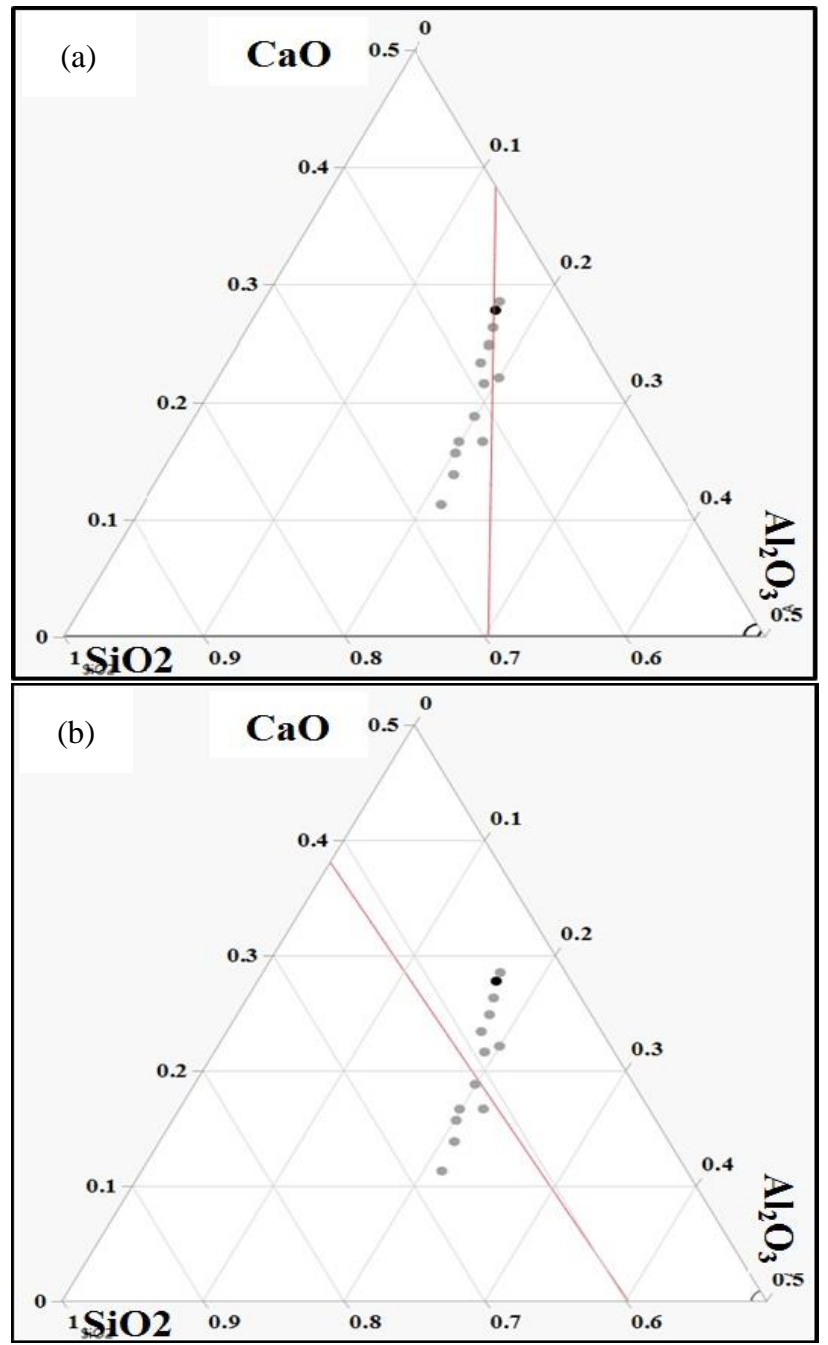

Fig. 9. Mixing profiler for treated and untreated soil (a) unconfined compressive strength and (b) plasticity index at the end of wettingdrying cycles.

Regarding durability, the cyclical wetting-drying exposure of the studied soils allows us to follow three determining indicators, namely, durability (volumetric variation in terms of expansion / retraction), the rate of water absorbed and compressive strength, depending on the lime percentage and curing period. We find that with higher lime contents, the majority of the studied soils can resist all 12 wetting-drying cycles. 
The soil microstructure is an important parameter in the establishment of hydraulic exchanges, which are liable to condition the behavior of soil in wetting-drying cycles. XRD analysis is the key to elucidating the lime stabilization reactions in soil. Analysis of lime treated soils revealed the formation of new hydrates $\mathrm{C}-\mathrm{S}-\mathrm{H}$ and $\mathrm{C}-\mathrm{A}-\mathrm{H}$. CH saturation in treated soil reduced by cation exchange, if $\mathrm{CEC}$ is higher, the $\mathrm{CH}$ in the interstitial solution of treated soil can be unsaturated. Thus the amount of $\mathrm{C}$ $\mathrm{S}-\mathrm{H}$ produced by the lime decreases by any further cation exchange can consume the $\mathrm{Ca}^{2+}$ and $\mathrm{OH}^{-}$ions that should be used to produce $\mathrm{C}-\mathrm{S}-\mathrm{H}$, which lowers the strength of soil.

The experimental design method has several advantages that can be summarized as follows: To obtain of the most information in a minimum number of experiments, i.e., to reduce the required number of tests to study a large number of factors and to detect the interactions between them, this method can be used to model with an optimum precision of the results.

Analysis of variance (ANOVA) of the experimental data was used to evaluate the importance of the effects on the response. A simple calculation model was proposed, allowing the determination of the UCS and PI at a cure time and wetting-drying cycle number. With this model, UCS and PI were calculated in terms of the chemical composition of the three main elements $\left(\mathrm{CaO}, \mathrm{SiO}_{2}\right.$ and $\left.\mathrm{Al}_{3} \mathrm{O}_{2}\right)$. The calculated results were in good agreement with the experimental results, confirming the major role played by the addition of lime and the effect of certain minerals on geotechnical properties of soil exposed to wetting-drying cycles.

We are invited to use new and very interesting methods and correlations for the control and characterization of treated soils properties, this method to become an industrial alternative because of its rapidity, ease and economy which can offer in terms of resources time and materials. Therefore, using this relationship for taking into account the specificities of each case, including the availability and cost of transport of each material. Choosing the amount of lime and suitable effort of compaction to provide a mix, this responds to required force by the project with best performance and less costs.

\section{Acknowledgement:}

The authors would like to thank the all authors and Laboratory of Environments, Water, Geomechanics and Ouvrage (L.E.E.G.O) and university of science and technology HOUARI BOUMEDIENE Algiers, Algeria.

\section{References}

[1] N. N. Maslov, P.L. Lvanov, Liquefaction conditions for saturated cohesion less soils, Proceedings of the eleventh international conference on soil Mechanics and Foundation Engineering, San Francisco, USA, 1985.

[2] A. A. Mustafayev, S.A. Mestchyan, J.A. Eyoubov, The rheology of subsidence and swelling soils, Proceedings of the eleventh international conference on soil Mechanics and Foundation Engineering, San Francisco, USA, 1985.

[3] Z. G. Ter-Martirosyan, Soil Mechanics, ASV, Moscow, Rusia, 550, 2009.

[4] N. K. Pekarskaya, The Shear Strength of Frozen Soils and Its Dependence on Texture, Izd. Akad. Nauk USSR, Moscow, Rusia, 1963.
[5] K. Hu, X. Chen, J. Chen, Laboratory investigation of deformation and strength characteristics of saline frozen silty sand, Soil Mech. Foundation Eng. 54 (2) (2017) 102-109. .

[6] H. Nowamooz, E. Jahangir, F. Masrouri, Volume change behavior of a swelling soil compacted at different initial states, Eng. Geol. 153 (2013) 25-34.

[7] K. Li, H. Nowamooz, C. Chazallon, B. Migault, Limit deformation analysis of unsaturated expansive Soils during wetting and drying cycles. Soil Mech. Foundation Eng. 55 (1) (2018) 1-7.

[8] A. Aldaood, M. Bouasker, M. Al-Mukhtaret, Impact of wetting-drying cycles on the microstructure and mechanical properties of lime-stabilized gypsums soils, Eng. Geol. 174 (2014) 11-21.

[9] A. N. Zelenin, Principles of Soil Crushing by Mechanical Methods, Mashinostroenie, Moscow, Rusia, 1968.

[10] V. I. Aksenov, Saline Frozen Soils of the Arctic Coast as Building Foundations, Vse o mire stroitel'stva, Moscow, Rusia, 2008.

[11] S.I. Pakhomov, A.M. Monyushko, Engineering-Geological Aspects of Technogenic Changes in the Properties of Clays, Nauka, Moscow, Rusia, 1988.

[12] Z. Shen, C.Yun, F. Lei, Experimental investigation of rapid stabilization of Soft clay soils using chemical admixtures, Soil Mech. Foundation Eng. 54 (3) (2017) 202-210.

[13] A. H. Al-Zoubaydi, I.M Al-Kiki, M. A. Al-Obaydi, Strength and durability of gypsums soil treated with waste lime and cement,. Al-Rafidain Eng. J. 18 (1) (2010) 28-42.

[14] A. H. Al-Zubaydi, M. A. Al-Atalla, I. M. Al-Kiki, Long term strength and durability of clayey soil stabilized with lime, Eng. Technol. J. 29 (4) (2011) 725-735.

[15] K. Lemaire, D. Deneele, S. Bonnet, M. Legret, Effects of lime and cement treatment on the physicochemical, microstructural and mechanical characteristics of a plastic silt, Eng. Geol. 166 (8) (2013) 255-261.

[16] F. Changizi, A. Haddad, Effect of nano- $\mathrm{SiO}_{2}$ on the geotechnical properties of cohesive soil, Geotech. Geol. Eng. 34 (2) (2016) 725-733.

[17] X. Huang, G. J. Zhou, Hardening mechanism of cementstabilized soil, Chin. J. Geotech. Eng. 16 (1) (1994) 62-68.

[18] Y. J. Cui, A. M. Tang, L. X. Qian, Thermal-mechanical behavior of compacted GMZ bentonite, Soils Foundation 51 (6) (2011) 1065-1073.

[19] D. Rothstein, J. J. Thomas, B. J. Christensen, H.M. Jennings, Solubility behavior of $\mathrm{Ca}-, \mathrm{S}-, \mathrm{Al}-$, and Si-bearing solid phases in Portland cement pore solutions as a function of hydration time, Cement Concr. Res. 32 (10) (2002) 16631671.

[20] N.C. Consoli, A. Dalla Rosa, M. B. Corte, L. D. S. Lopes Jr, B. S. Consoli, Porosity-cement ratio controlling strength of artificially cemented clays, J. Mater. Civ. Eng. 23 (8) (2011) $1249-1254$.

[21] A. V. da Fonseca, R.C. Cruz, N. C. Consoli, Strength properties of sandy soil-cement mixtures, Geotech. Geol. Eng. 27 (6) (2009) 681-686.

[22] American Society for Testing and Materials, Test Method for Liquid Limit, Plastic Limit, and Plasticity Index of Soils. ASTM D 4318 (2000). ASTM International, West Conshohocken, PA, 2000.

[23] American Society for Testing and Materials, Standard Test Method for Methylene Blue Index of Clay. ASTM C837- 
09(2014). ASTM International, West Conshohocken, PA, 2014.

[24] American Society for Testing and Materials, Standard Test Method for Particle-Size Analysis of Soils (Withdrawn 2016). ASTM D422-61(2007)e2. ASTM International, West Conshohocken, PA, 2007.

[25] American Society for Testing and Materials, Standard Test Method for using $\mathrm{pH}$ to estimate the soil - lime proportion requirement for soil stabilization. ASTM D6276-99a. ASTM International, West Conshohocken, PA, 1999.

[26] American Society for Testing and Materials Standard Test Methods for One-Dimensional Swell or Collapse of Soils. ASTM D4546-14. ASTM International, West Conshohocken, PA, 2014.

[27] American Society for Testing and Materials, Standard Practice for Classification of Soils for Engineering Purposes (Unified Soil Classification System). ASTM D2487-11. ASTM International, West Conshohocken, PA, 2011.

[28] American Society for Testing and Materials, Standard Test Methods for Laboratory Determination of Water (Moisture) Content of Soil and Rock by Mass. ASTM D2216-10. ASTM International, West Conshohocken, PA, 2010.

[29] American Society for Testing and Materials, Standard test methods for laboratory compaction characteristics of soil using standard effort (12 $400 \mathrm{ft}-\mathrm{lbf} / \mathrm{ft} 3(600 \mathrm{kN}-\mathrm{m} / \mathrm{m} 3))$. ASTM D 698. (2012). Vol. 4.08. ASTM International, West Conshohocken, PA, 2012.

[30] American Society for Testing and Materials, Standard Test Methods for Wetting and Drying Compacted Soil-Cement Mixtures. ASTM D559. ASTM International, West Conshohocken, PA, 2015.

[31] American Society for Testing and Materials, Standard Test Method for Unconfined Compressive Strength of Compacted
Soil-Lime Mixtures (Withdrawn 2018). ASTM D5102-09. ASTM International, West Conshohocken, PA, 2009.

[32] United States Environmental Protection Agency, Test Method 9081: Cation-Exchange Capacity of Soils (Sodium Acetate). US EPA 9081. Washington, DC, USA, 1986.

[33] Code of China, Standard for soil test method. GB/T 501231999, Beijing, China, 1999.

[34] T. Y. Elkady, The effect of curing conditions on the unconfined compression strength of lime-treated expansive soils, Road Mater. Pave. Des. 17 (1) (2016) 52-69.

[35] T. T. H. Nguyen, Stabilisation des sols traites à la chaux et leur comportement au gel [Stabilization of lime-treated soils and their freeze-thaw behavior], (Doctoral Disertation), Université Paris-Est, France, 2015.

[36] A. Al-Taie, M. Disfani, R. Evans, A. Arulrajah, S. Horpibulsuk, Impact of curing on behaviour of basaltic expansive clay, Road Mater. Pave. Des. 19 (3) (2018) 624645.

[37] S. Saride, A. J. Puppala, S. R. Chikyala, Swell-shrink and strength behaviors of lime and cement stabilized expansive organic clays, Appl. Clay Sci. 85 (1) (2013) 39-45.

[38] Q. Cheng, K. Yao, Y. Liu, Stress-Dependent Behavior of Marine Clay Admixed with Fly-Ash-Blended Cement, Inter, J, Pave. Res. Technol. 11 (6) (2018) 611-616.

[39] K. H.Mamatha, S. V.Dine, Resilient modulus of black cotton soil, Inter, J, Pave. Res. Technol. 10 (2) (2017) 171-184.

[40] P. J. Vardanega, C. L. Hickey, K. Lau, H. D. L. Sarzier, C. M. Couturier, G. Martin, Investigation of the Atterberg limits and untrained fall-cone shear strength variation with water content of some peat soils, Inter. J. Pave. Res. Technol. 12 (2) (2019) 131-138. 